\title{
Marine Terpenoid Diacylguanidines: Structure, Synthesis, and Biological Evaluation of Naturally Occurring Actinofide and Synthetic Analogues
}

Marianna Carbone, ${ }^{\dagger}$ M. Letizia Ciavatta, ${ }^{\dagger}$ Véronique Mathieu, ${ }^{\ddagger}$ Aude Ingels, ${ }^{\ddagger}$ Robert Kiss, ${ }^{\ddagger}$ Paola Pascale, ${ }^{\dagger}$ Ernesto Mollo, ${ }^{\dagger}$ Nicon Ungur, ${ }^{\S}$ Yue-Wei Guo, ${ }^{*, \perp}$ and Margherita Gavagnin ${ }^{*}{ }^{\dagger}$ (i)

${ }^{\dagger}$ Consiglio Nazionale delle Ricerche (CNR), Istituto di Chimica Biomolecolare (ICB), Via Campi Flegrei, 34, 80078 Pozzuoli (Na), Italy

${ }^{\ddagger}$ Laboratoire de Cancérologie et de Toxicologie Expérimentale, Faculté de Pharmacie, Université Libre de Bruxelles (ULB), Campus de la Plaine, Boulevard du Triomphe, 1050 Brussels, Belgium

${ }^{\S}$ Institute of Chemistry, Moldova Academy of Sciences, Academiei str. 3, MD-2028 Chisinau, Republic of Moldova

${ }^{\perp}$ State Key Laboratory of Drug Research, Shanghai Institute of Materia Medica, Chinese Academy of Sciences, Shanghai 201203, P.R. China

\section{Supporting Information}

ABSTRACT: A new diacylguanidine, actinofide (1), has been isolated from the marine mollusk Actinocyclus papillatus. The structure, exhibiting a guanidine moiety acylated by two terpenoid acid units, has been established by spectroscopic methods and secured by synthesis. Following this, a series of structural analogues have been synthesized using the same procedure. All of the compounds have been evaluated in vitro for the growth inhibitory activity against a variety of cancer cell lines.

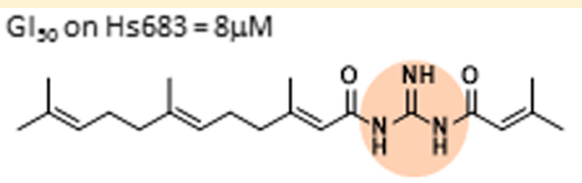

actinofide from Actinocyclus papillatus
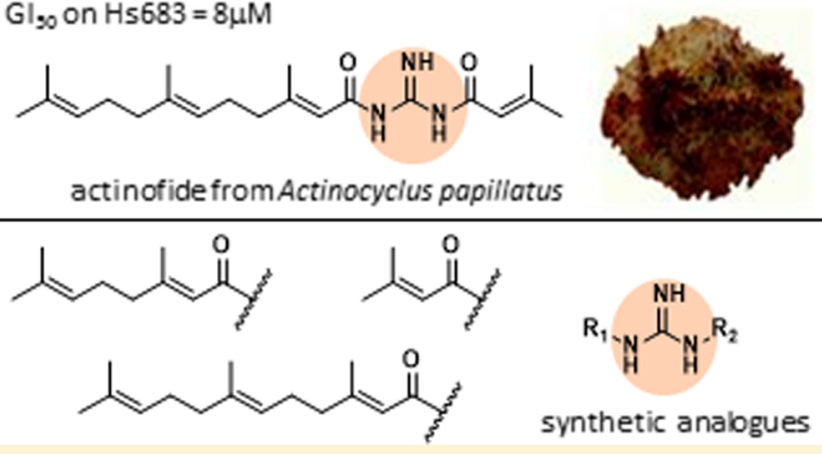

synthetic analogues uanidine compounds present a wide species distribution, Structurally, natural guanidines include pyrimidine derivatives, peptides, polyketides, and terpenes. ${ }^{1}$ In guanidines isolated from marine organisms, in particular, the guanidine moiety is very often incorporated in peptide, polyketide, and aromatic metabolites, whereas terpenoid guanidines are less frequently isolated. ${ }^{2,3}$

Guanidines are highly valued in various biological, biochemical, and medical applications. ${ }^{4}$ Potent biological activities, such as anti-inflammatory, antiprotozoal, anti-HIV, chemotherapeutic, and antidiabetic, ${ }^{5,6}$ have been shown by numerous natural and synthetic guanidines. Among them, acylguanidines are greatly appreciated because they may be considered as considerably less basic bioisosteres of guanidines with improved pharmacokinetics and pharmacodynamics on various biological targets. ${ }^{7,8}$ The basicity of the acylguanidines $\left(\mathrm{p} K_{\mathrm{a}}\right.$ values around 8 ) is $4-5$ orders of magnitude lower than that of the corresponding guanidines. Hence, on one hand, acylguanidines are sufficiently basic to undergo key interactions with acidic residues of the receptor, whereas, on the other hand, a considerable portion remains uncharged at physiological $\mathrm{pH}$, thus facilitating diffusion across membranes.
Our continuing chemical studies on marine shell-less mollusks aim to identify new bioactive metabolites. ${ }^{10}$ As such, we have previously described two indole guanidines, phidianidines $\mathrm{A}$ and $\mathrm{B}$ from the aeolidacean nudibranch Phidiana militaris collected at the South China Sea, that exhibited very promising biological properties. ${ }^{11}$ Herein, we report a diacylguanidine compound, actinofide (1), from the skin of the dorid nudibranch Actinocyclus papillatus, collected at the same location. The previous chemical investigation of this mollusk had resulted in the identification of the main metabolite of the skin extract, actisonitrile, ${ }^{12}$ which is not structurally related to 1 .

With the aim at both securing the structure and obtaining a larger amount of compound for biological screening, the synthesis of actinofide (1) was performed as described below. In addition, the interesting growth inhibitory activity against various cancer cell lines observed for compound 1 prompted the preparation of a series of structural analogues 2-9 to be assayed along with $\mathbf{1}$ (Chart 1 ). Finally, the related terpenoid diacylguanidine dotofide (10), previously described from the aeolidacean nudibranch Doto pinnatifida by König et al., ${ }^{13}$ was

Received: October 13, 2016

Published: April 13, 2017 


\section{Chart 1}

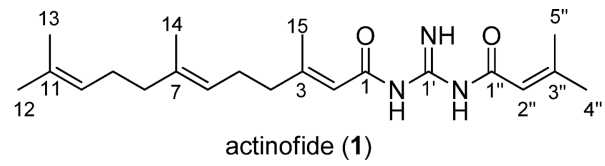<smiles>CC(C)=CCC/C(C)=C/CC/C(C)=C/C(=O)NC(=N)N</smiles><smiles>CC(C)=CCC/C(C)=C/C(=O)NC(=N)N</smiles>

3<smiles>CC(C)=CC(=O)NC(=N)N</smiles>

4<smiles>CC(C)=CCC/C(C)=C/CC/C(C)=C/C(=O)NC(=N)NC(=O)/C=C(\C)CC/C=C(\C)CCC=C(C)C</smiles><smiles>CC(C)=CCC/C(C)=C/C(=O)NC(=N)NC(=O)/C=C(\C)CCC=C(C)C</smiles>

6<smiles>[3H]C(=O)NC(=N)NC(=O)C=C(C)C</smiles><smiles>CC(C)=CCC/C(C)=C/C(=O)NC(=N)NC(=O)C=C(C)C</smiles><smiles>CC(C)=CCC/C(C)=C/CC/C(C)=C/C(=O)NC(=N)NC(=O)/C=C(\C)CCC=C(C)C</smiles>

8<smiles>C=C1CCCC(C)[C@@H]1CC/C(C)=C/C(=O)NC(=N)NC(=O)C=C(C)C</smiles>

purified from a collection of $D$. pinnatifida caught in the bay of Naples and submitted to the same biological screening.

\section{RESULTS AND DISCUSSION}

Actinofide (1) was purified from the skin extract of a single individual of A. papillatus, collected by SCUBA along the coast of Wei Zhou Island (South China Sea) during May 2007. As already described, ${ }^{12}$ the $\mathrm{Et}_{2} \mathrm{O}$ soluble portion $(172.1 \mathrm{mg}$ ) of the acetone extract of the skin had been fractionated by Sephadex LH20 followed by silica gel chromatography to isolate the main metabolite, actisonitrile. Selected fractions recovered from the $\mathrm{SiO}_{2}$ column that were not considered in the previous work ${ }^{12}$ have been now analyzed and submitted to preparative TLC purification (petroleum ether $/ \mathrm{Et}_{2} \mathrm{O}, 1: 1$ ) to obtain pure actinofide $(1,1.3 \mathrm{mg})$. An additional aliquot $(2.7 \mathrm{mg})$ of compound 1 was isolated as the protonated form by purifying fractions of the extract on reversed-phase high-performance liquid chromatography (HPLC, Supelco Discovery C18 column, $\mathrm{MeOH} / \mathrm{H}_{2} \mathrm{O}$ gradient with $0.1 \%$ of TFA).

The molecular formula of actinofide (1), $\mathrm{C}_{21} \mathrm{H}_{33} \mathrm{~N}_{3} \mathrm{O}_{2}$, was deduced from the $[\mathrm{M}+\mathrm{H}]^{+}$peak at $360.2645 \mathrm{~m} / z$ in the HRESIMS spectrum. The IR spectrum showed bands at 3345 , 1731 , and $1633 \mathrm{~cm}^{-1}$ according to the presence of amino and carbonyl functions. In the ${ }^{13} \mathrm{C}$ NMR spectrum $\left(\mathrm{CD}_{3} \mathrm{OD}\right)$, eight olefinic carbon signals were recognized at $\delta_{\mathrm{C}} 160.3(\mathrm{C}, \mathrm{C}-3)$, 156.6 (C, C-3'), 136.6 (C, C-7), 132.2 (C, C-11), $125.3(\mathrm{CH}$, $\mathrm{C}-10), 124.4(\mathrm{CH}, \mathrm{C}-6), 121.9\left(\mathrm{CH}, \mathrm{C}-2^{\prime \prime}\right)$, and 121.7 (CH, C2 ), consistent with the presence of four trisubstituted double bonds, two of which were $\alpha, \beta$-unsaturated. According to this, the ${ }^{1} \mathrm{H}$ NMR spectrum displayed signals due to four vinylic protons $\left[\delta_{\mathrm{H}} 5.85\left(2 \mathrm{H}\right.\right.$, br s, $\mathrm{H}-2$ and $\left.\mathrm{H}-2^{\prime \prime}\right), 5.15(1 \mathrm{H}, \mathrm{m}, \mathrm{H}-6)$, $5.12(1 \mathrm{H}, \mathrm{m}, \mathrm{H}-10)]$ and to six vinyl methyl groups $\left[\delta_{\mathrm{H}} 2.21\right.$ $\left(6 \mathrm{H}\right.$, br s, $\mathrm{H}_{3}-15$ and $\left.\mathrm{H}_{3}-5^{\prime \prime}\right), 1.94\left(3 \mathrm{H}, \mathrm{s}, \mathrm{H}_{3}-4^{\prime \prime}\right), 1.69(3 \mathrm{H}, \mathrm{s}$, $\left.\left.\mathrm{H}_{3}-12\right), 1.65\left(3 \mathrm{H}, \mathrm{s}, \mathrm{H}_{3}-14\right), 1.62\left(3 \mathrm{H}, \mathrm{s}, \mathrm{H}_{3}-13\right)\right]$. The ${ }^{1} \mathrm{H}$ NMR spectrum was completed by multiplets at $\delta_{\mathrm{H}} 2.25-1.98$ that were attributable to four methylenes adjacent to double bonds. These data were consistent with two linear unsaturated isoprenoid arrangements each containing a carbonyl residue. Analysis of 2D NMR experiments, which were recorded in both $\mathrm{CDCl}_{3}$ and $\mathrm{CD}_{3} \mathrm{OD}$, led us to recognize farnesoyl and 3,3dimethylacryloyl (senecioyl) moieties. The remaining structural fragment $\mathrm{CH}_{3} \mathrm{~N}_{3}$ required by the molecular formula was suggested to have the Y-shaped arrangement of a guanidine functional group $\left(\delta_{\mathrm{CN}} 159.2\right)$ and to be connected to both terpenoyl moieties by an acyl linkage as depicted in structure $\mathbf{1}$. The signal resonating at $\delta_{\mathrm{C}} 175.4\left(\mathrm{CD}_{3} \mathrm{OD}\right)$ and 172.7 
Scheme 1. Synthesis of Actinofide (1) ${ }^{a}$

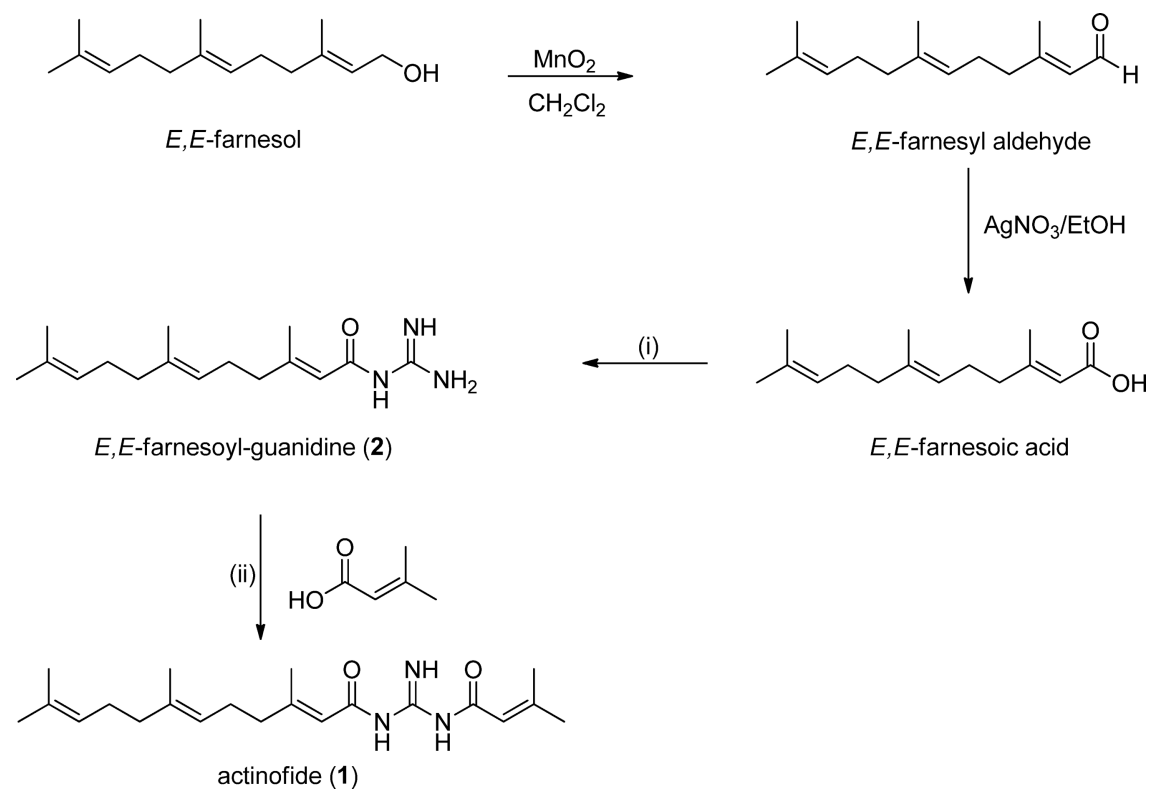

${ }^{a}$ Conditions: (i) CDI, DMF then addition to a guanidine solution in DMF/dioxane; (ii) 3,3-dimethyl acrylic acid, N-methylpyrrolidone, 2-chloro-1methyl pyridinium iodide, $\mathrm{rt}, 30 \mathrm{~min}, 50^{\circ} \mathrm{C}, 1 \mathrm{~h}$, then addition of guanidine derivative 2 and DIEA at $\mathrm{rt}, 12 \mathrm{~h}$.

Table 1. Determination of the Antiproliferative Activities $\left(\mathrm{GI}_{50}\right.$ values, $\left.\mu \mathrm{M}\right)$ of Compounds $1-10$ Using the MTT Colorimetric Assay $^{a, b}$

\begin{tabular}{|c|c|c|c|c|c|c|}
\hline \multirow[b]{2}{*}{ compound } & \multicolumn{2}{|c|}{ glioma } & \multicolumn{2}{|c|}{ carcinoma } & \multicolumn{2}{|c|}{ melanoma } \\
\hline & $\mathrm{Hs} 683^{c}$ & U373 & A549 & MCF7 & SKMEL-28 & $\mathrm{B} 16 \mathrm{~F} 10$ \\
\hline 1 & $8.3 \pm 1.8$ & $15.7 \pm 10.1$ & $23.4 \pm 5.5$ & $23.4 \pm 5.9$ & $24.2 \pm 8.2$ & $7.5 \pm 3.1$ \\
\hline 2 & 10.0 & 21.0 & 13.7 & 22.0 & 20.1 & 9.2 \\
\hline 3 & 39.4 & 46.0 & 76.5 & 52.2 & 56.3 & 17.1 \\
\hline 4 & $>100$ & $>100$ & $>100$ & $>100$ & $>100$ & 92.8 \\
\hline 5 & 6.8 & 9.2 & 18.5 & 30.3 & 42.7 & 5.7 \\
\hline 6 & 32.7 & 38.9 & 46.9 & 42.4 & 61.9 & 23.8 \\
\hline 7 & 60.3 & 45.6 & 75.6 & 59.7 & $>100$ & 21.3 \\
\hline 8 & 31.5 & 36.2 & 37.4 & 41.5 & 53.4 & 25.0 \\
\hline 9 & 37.4 & 35.0 & 38.9 & 51.2 & 57.3 & 18.9 \\
\hline 10 & 18.1 & 28.8 & 29.4 & 28.1 & 60.5 & 9.6 \\
\hline etoposide $^{d}$ & 1.5 & 24.9 & 1.7 & 4.0 & 3.2 & $\mathrm{nd}^{e}$ \\
\hline carboplatin $^{d}$ & 45.6 & 27.6 & 53.5 & $\mathrm{nd}^{e}$ & 68.6 & 34.9 \\
\hline
\end{tabular}

${ }^{a}$ Data are represented as the $\mathrm{GI}_{50}$ concentration $(\mu \mathrm{M})$, i.e., the compound concentration that reduces by $50 \%$ the growth of a given cell line (as compared to the control value) after having cultured the cells for $72 \mathrm{~h}$ with the compound of interest. ${ }^{b}$ Each experiment was carried out once in six replicates, except for compound $\mathbf{1}$, for which the presented results are the mean of two independent assays conducted each in sextuplicate. ${ }^{c}$ The origin and histological type of each cell line analyzed are as follows. Human glioma model lines included the Hs683 oligodendroglioma (ATCC code HTB-138) and the U373 glioblastoma (ECACC code 08061901) cell lines. Melanoma models included the human SKMEL-28 (ATCC code HTB72 ) and the mouse B16F10 (ATCC code CRL-6475) cell lines. Human carcinoma models included the A549 NSCLC (DSMZ code ACC107) and the MCF-7 breast (DSMZ code ACC115). ${ }^{d}$ The selected positive control compounds are drugs routinely used in cancer treatment. The $\mathrm{GI}_{50}$ concentrations reported in the table were obtained partly in our previous experiments. ${ }^{10,32}{ }^{e}$ Not determined.

$\left(\mathrm{CDCl}_{3}\right)$ was determined to represent both $\mathrm{C}-1$ and $\mathrm{C}-1^{\prime \prime}$ carbonyls by analysis of diagnostic HMBC correlations with distinguishable $\mathrm{H}-2\left(\delta_{\mathrm{H}} 5.77\right)$ and $\mathrm{H}-2^{\prime \prime}\left(\delta_{\mathrm{H}} 5.78\right)$ protons in the $\mathrm{CDCl}_{3}$ spectrum of 1 . The $E$ configuration of the internal $\Delta^{5}$ and $\Delta^{9}$ double bonds in the farnesoyl moiety was determined on the basis of chemical shift value of C-14 $\left(\delta_{\mathrm{C}}\right.$ 16.1) and $\mathrm{C}-15\left(\delta_{\mathrm{C}} 20.4\right.$ or 19.1).

Actinofide (1) is structurally related to the previously described dotofide (10) differing in the presence of a linear $\mathrm{C}_{15}$ isoprenoid moiety rather than the monocyclic farnesoic unit. ${ }^{13} \mathrm{~A}$ few terpenoid guanidine compounds including agelasidines and bistellettadines have been reported from the sea. ${ }^{8,9}$ Although terpenoid guanidines are not so frequently encountered in marine organisms, a number of these compounds have been isolated from different higher plant families, mainly from species belonging to the families Euphorbiaceae and Leguminosae. ${ }^{14}$ All terrestrial terpenoid guanidines show a structure with the guanidine unit connected to isoprenyl residues by amino rather than amido linkages.

Despite their low occurrence, guanidine terpenoids have shown a large spectrum of biological activities, standing out as promising lead structures suitable for development of potential drugs. ${ }^{15}$ As an example, recent studies have indicated the ability of some of these compounds (e.g., nitensidine A) to modulate 
the activity of human P-glycoprotein ABCB1, a transmembrane efflux pump belonging to the ATP-binding cassette (ABC) transporter superfamily, which is involved in cancer multidrug resistance. $^{16}$

No bioactivity data have been reported for marine guanidine terpenoids. Thus, we decided to investigate the in vitro growth inhibitory activity of actinofide (1) against a series of human and mouse cancer cell lines. With the aim at getting a larger amount of product for the biological screening, the synthesis of actinofide (1) (Scheme 1) was performed, based on the coupling of guanidine with two terpenoid acid units in two sequential steps, according to the synthetic procedure recently reported for dotofide (10). ${ }^{17}$ First, farnesoic acid activated with carbonyldiimidazole (CDI) in dimethylformamide (DMF) was treated with guanidine to obtain monofarnesoyl derivative 2 . An aliquot of the reaction product was purified by preparative TLC to get a pure sample of monofarnesoyl derivative 2 for spectroscopic characterization, whereas the remaining part was used without purification in the subsequent step. In this step, compound $\mathbf{2}$ was allowed to react in slight excess with the adduct formed by 3,3-dimethyl acrylic acid activated with Mukaiyama reagent (2-chloro-1-methylpyridinium iodide), in the presence of $\mathrm{N}$-diisopropyldiethylamine (DIEA). The resulting diacylguanidine derivative was isolated from the reaction mixture and purified by silica gel chromatography (petroleum ether $/ \mathrm{Et}_{2} \mathrm{O}$ gradient). It showed spectroscopic data $\left({ }^{1} \mathrm{H}\right.$ and $\left.{ }^{13} \mathrm{C} \mathrm{NMR}, \mathrm{MS}\right)$ identical with those of natural actinofide (1).

Subsequently, using the same synthetic scheme, ${ }^{17}$ a series of actinofide analogues, compounds 3-9, differing in the terpenoid moiety linked to guanidine were also prepared to be assayed along with natural 1. Senecioic (3,3-dimethyl acrylic), farnesoic, and geranoic acids were selected to prepare the monoacyl derivatives $\mathbf{3}$ and $\mathbf{4}$ as well as diacylguanidine derivatives 5-9 exhibiting a different combination of $\mathrm{C}_{5}, \mathrm{C}_{10}$, and $\mathrm{C}_{15}$ terpenoid units. All compounds were characterized by MS and NMR spectroscopy.

Finally, a sample of natural dotofide (10) was also tested for the growth inhibitory activity together with guanidines 1-9. The sample was obtained as described in the Experimental Section from a population of the nudibranch $D$. pinnatifida collected in the bay of Naples and identified by ${ }^{1} \mathrm{H}$ NMR and MS spectra and specific rotation. ${ }^{13}$

Acylguanidine terpenoids $\mathbf{1 - 1 0}$ were assayed by means of the MTT colorimetric assay (Table 1 ), which provides a $\mathrm{GI}_{50}$ index as detailed previously. ${ }^{18-20}$ Six cancer cell lines of distinct histological origins were used, that is, two human carcinoma cancer cell lines [MCF-7 (breast) and A549 (nonsmall cell lung cancer; NSCLC)] of epithelial origin, ${ }^{21}$ two human cancer cell lines from glial origin [i.e., the Hs683 oligodendroglioma ${ }^{22,23}$ and the U373 glioblastoma (of astrocytic origin) models], ,2,24 and two melanoma models (i.e., the mouse $\mathrm{B} 16 \mathrm{~F} 10^{18,25}$ and the human SKMEL-28 cell lines). ${ }^{18,25}$ These cancer cell lines have been chosen because they display various levels of sensitivity to pro-apoptotic stimuli, knowing that the resistance to proapoptotic stimuli currently represents one of the major failures in cancer chemotherapy. Indeed, evasion of apoptosis is a requirement for both neoplastic transformation and sustained growth of cancer cells. ${ }^{26,27}$ In addition, $~ 90 \%$ of cancer patients die from their metastases, ${ }^{28}$ and metastatic cancers are resistant to pro-apoptotic stimuli. ${ }^{28,29}$ Thus, cytotoxic compounds that kill cancer cells through non-apoptotic cell death are likely to become innovative anticancer agents. ${ }^{30}$ Each melanoma and glioma pair of cancer cell lines under study accordingly displays distinct levels of sensitivity to pro-apoptotic stimuli. Indeed, the Hs683 oligodendroglioma cells display higher sensitivity to temozolomide, ${ }^{22,24}$ fotemustine, ${ }^{22}$ carmustine, ${ }^{22}$ podophylotoxin, ${ }^{19}$ combretastatin, ${ }^{19}$ and higginsianin $A^{20}$ than U373 glioblastoma cells. In the same manner, mouse B16F10 melanoma cells display higher sensitivity to taxol, ${ }^{18}$ adriamycin, ${ }^{18}$ and narciclasine ${ }^{25}$ than human SKMEL-28 melanoma cells. While breast MCF-7 cancer cells are caspase- 3 deficient, they nevertheless respond to pro-apoptotic stimuli. ${ }^{21}$ The A549 NSCLC cells display various markers of chemoresistance. ${ }^{31}$

The available SAR data shown in Table 1 revealed that the degree of the growth inhibitory activity appears to be almost affected by the size of terpenoid units linked to the guanidine unit. Even though there was not a strictly linear correlation for all cancer cell lines, some considerations could be made. More efficient acylguanidines were compounds $1,2,5$, and 10, all exhibiting one or two $\mathrm{N}-\mathrm{C}_{15}$ residues, whereas, surprisingly, compound 9, also containing a farnesoyl substituent along with the $\mathrm{C}_{10}$ terpenoid acyl unit, displayed weaker activities against all cell lines. Dotofide (10) containing a cyclic farnesoyl moiety was less active than the corresponding acyclic actinofide (1), suggesting that the cyclization negatively influenced the activity degree. Senecioyl guanidine (4) with the shortest terpenoid residue was inactive against all cell lines. The introduction of the second senecioyl substituent in diacyl derivative 7 resulted in a positive impact on the antiproliferative activity, in particular, against the melanoma B16F10 model, most likely due to the increased hydrophobicity of the molecule. On the other side, monoacylguanidines 2 and 3 with $\mathrm{C}_{15}$ and $\mathrm{C}_{10}$ alkyl chains displayed, in almost cancer cell lines, $\mathrm{GI}_{50}$ values comparable with those of the corresponding diacyl derivatives 5 and 6, respectively, suggesting that in this case the symmetrical diacylation did not significantly influence the inhibitory activity. However, these preliminary considerations should be confirmed by further studies aimed at the biological evaluation of a larger number of terpenoid guanidine derivatives. Among the small collection of analogues described here, the best biological profile was observed for $N, N^{\prime}$-difarnesoyl guanidine (5) displaying growth inhibitory effects that ranged between those displayed by etoposide and carboplatin. Some interesting points could be highlighted. For example, while U373 glioblastoma cells are about 10 times less sensitive to etoposide than Hs683 oligodendroglial cells, compound 5 displays similar growth inhibitory effects in these two brain cancer models (Table 1). In contrast, compound $\mathbf{5}$ displays weaker growth inhibitory effects in the melanoma SKMEL-28 model when compared to the B16F10 one (Table 1). It is well-known that the molecular and biochemical mechanisms leading to the resistance to pro-apoptotic stimuli markedly differ between gliomas $^{33}$ and melanomas. ${ }^{34}$ The data from the present study thus suggest that some compounds, as for example 5, may exert actual in vitro antiproliferative effects against apoptosis-resistant cancers such as glioblastoma but not against any type of apoptosis-resistant cancer types. The in vitro antiproliferative effects displayed by $\mathbf{5}$ would be selective for certain targets in specific cancer cell types. Further studies will be necessary to clarify these aspects.

In conclusion, a new terpenoid diacylguanidine, actinofide (1), was isolated from a marine mollusk collected in the South China Sea and chemically characterized by spectroscopic methods. The structure was secured by synthesis. Actinofide (1) was evaluated for the growth inhibitory activity against a 
number of cancer cell lines, along with known natural dotofide (10) and a series of analogues 2-9 that were opportunely prepared by using the same synthesis strategy. Among all tested compounds, the synthetic derivative $N, N^{\prime}$-difarnesoyl guanidine (5) showed the most interesting biological activity profile, suggesting a possible selective interaction with specific cancer cell lines.

\section{EXPERIMENTAL SECTION}

General Experimental Procedures. Optical rotations were measured on a Jasco DIP 370 digital polarimeter. UV spectra were recorded on a Beckman Coulter DU 730 spectrophotometer. Fourier transform infrared spectra were obtained using a Spectrum 100 instrument from PerkinElmer fitted with a germanium $/ \mathrm{KBr}$ beam splitter and a deuterated triglycine sulfate wide-band detector on $\mathrm{KBr}$ pellets. NMR experiments were recorded at the ICB-NMR Service Centre on a DRX $600 \mathrm{MHz}$ Bruker spectrometer equipped with a TXI cryoprobe and on a Bruker Avance- 400 spectrometer using an inverse probe fitted with a gradient along the $Z$-axis. The NMR spectra were acquired in $\mathrm{CDCl}_{3}$ and $\mathrm{CD}_{3} \mathrm{OD}$, and the chemical shifts were reported in parts per million referring to $\mathrm{CHCl}_{3}\left(\delta_{\mathrm{H}} 7.26\right.$ for proton and $\delta_{\mathrm{C}} 77.0$ for carbon) and $\mathrm{MeOH}\left(\delta_{\mathrm{H}} 3.34\right.$ for proton and $\delta_{\mathrm{C}} 49.0$ for carbon), respectively. ESIMS spectra were measured on a Micromass Q-TOF Micro spectrometer coupled with an HPLC Waters Alliance 2695. HRESIMS spectra were recorded on a Thermo Q-Exactive spectrometer coupled with a UHPLC Agilent Infinity 1290 and on a Shimadzu IT-TOF spectrometer equipped with an ESI interface. Analytical and preparative TLC were performed on precoated silica gel plates (Merck Kieselgel $60 \mathrm{~F} 254,0.2 \mathrm{~mm}$ and $0.5 \mathrm{~mm}$ ), with detection provided by UV light $(254 \mathrm{~nm})$ and by spraying with ceric sulfate $\left(\mathrm{CeSO}_{4}\right)$ reagent followed by heating. Silica gel column chromatography was performed using Merck Kieselgel 60 powder (0.063-0.200 $\mathrm{mm}$ ), whereas size-exclusion chromatography was achieved on a Sephadex LH20 column. HPLC purifications were carried out on a Shimadzu LC-10AD liquid chromatograph equipped with a UV SPD$10 \mathrm{~A}$ wavelength detector. All the reagents were purchased from SigmaAldrich and used such as received.

Biological Material. One individual of Actinocyclus papillatus (size $14 \mathrm{~cm}$ ) was sampled by SCUBA in the South China Sea along the coast of Wei Zhou Island, China $\left(21^{\circ} 00^{\prime} \mathrm{N}, 109^{\circ} 04^{\prime} \mathrm{E}\right)$, during May 2007. ${ }^{12}$ The animal was frozen at $-20{ }^{\circ} \mathrm{C}$ and transferred to ICB (Italy). Collection of Doto pinnatifida was undertaken in the salt lake of Lucrino in Pozzuoli, Naples, Italy $\left(40^{\circ} 49^{\prime} \mathrm{N}, 14^{\circ} 04^{\prime} \mathrm{E}\right)$, during October 2014. The mollusks (60 individuals, average size $0.5 \mathrm{~cm}$ ) were collected by SCUBA and taken back to the ICB laboratory where they were stored at $-20{ }^{\circ} \mathrm{C}$ until extraction.

Extraction and Purification of Actinofide (1). As previously described, ${ }^{12}$ the mantle of $A$. papillatus, obtained by dissection, was extracted by acetone $(3 \times 50 \mathrm{~mL})$ at room temperature $(\mathrm{rt})$. The filtered acetone solution was concentrated, and the residual $\mathrm{H}_{2} \mathrm{O}$ was extracted with $\mathrm{Et}_{2} \mathrm{O}(3 \times 50 \mathrm{~mL})$, obtaining, after evaporation of the organic solvent, $172.1 \mathrm{mg}$ of crude material. The composition of this extract was compared with that of the corresponding extract of the mollusk inner organs ${ }^{12}$ by TLC chromatography (petroleum ether/ $\mathrm{Et}_{2} \mathrm{O}$ in several ratios) detecting the spots with $\mathrm{CeSO}_{4}$ reagent. The $\mathrm{Et}_{2} \mathrm{O}$ soluble portion of the mantle acetone extract was fractionated on a Sephadex LH20 column $\left(\mathrm{CHCl}_{3} / \mathrm{MeOH}, 1: 1\right)$, affording a fraction $(18.5 \mathrm{mg})$ containing actinofide (1) along with the actisonitrile. ${ }^{12}$ This fraction was further purified by silica gel chromatography (petroleum ether $/ \mathrm{Et}_{2} \mathrm{O}$ gradient) to give pure actisonitrile ${ }^{12}$ and a series of fractions in which actinofide (1) was present in a mixture with fatty acids. Part of these fractions were combined and purified by preparative $\mathrm{SiO}_{2}$ TLC (petroleum ether/ $\mathrm{Et}_{2} \mathrm{O}, 1: 1$ ) to obtain pure actinofide $(1,1.3 \mathrm{mg})$. The remaining fractions were combined and purified on reversed-phase HPLC [Supelco Discovery C18 $(25 \mathrm{~cm} \times$ $10 \mathrm{~mm}, 5 \mu \mathrm{m}$ ) column, $35 \mathrm{~min}$ gradient from 50 to $100 \% \mathrm{MeOH}$ in $\mathrm{H}_{2} \mathrm{O}$ with $0.1 \%$ of TFA, flow $2 \mathrm{~mL} / \mathrm{min}$, UV detector at $\lambda=210$ and $254 \mathrm{~nm}$ ] to get $2.7 \mathrm{mg}$ of pure actinofide (1) recovered as the protonated form (the TFA salt).
Actinofide (1): colorless oil; UV (MeOH) $\lambda_{\max }(\log \varepsilon) 239$ (4.22), 272 (4.35); IR (liquid film) $\nu_{\max } 3345,1731,1633,1125 \mathrm{~cm}^{-1} ;{ }^{1} \mathrm{H}$ NMR of the neutral form $\left(\mathrm{CDCl}_{3}, 400 \mathrm{MHz}\right) \delta_{\mathrm{H}} 5.78\left(1 \mathrm{H}, \mathrm{s}, \mathrm{H}-2^{\prime \prime}\right)$, $5.77(1 \mathrm{H}, \mathrm{s}, \mathrm{H}-2), 5.08(2 \mathrm{H}, \mathrm{m}, \mathrm{H}-6$ and $\mathrm{H}-10), 2.20\left(6 \mathrm{H}, \mathrm{br} \mathrm{s}, \mathrm{H}_{3}-15\right.$ and $\left.\mathrm{H}_{3}-5^{\prime \prime}\right), 2.17\left(4 \mathrm{H}, \mathrm{m}, \mathrm{H}_{2}-4\right.$ and $\left.\mathrm{H}_{2}-5\right), 2.19\left(2 \mathrm{H}, \mathrm{m}, \mathrm{H}_{2}-5\right), 2.05$ $\left(2 \mathrm{H}, \mathrm{m}, \mathrm{H}_{2}-9\right), 1.98\left(2 \mathrm{H}, \mathrm{m}, \mathrm{H}_{2}-8\right), 1.91\left(3 \mathrm{H}, \mathrm{s}, \mathrm{H}_{3}-4^{\prime \prime}\right), 1.68(3 \mathrm{H}, \mathrm{s}$, $\left.\mathrm{H}_{3}-12\right), 1.60\left(6 \mathrm{H}\right.$, br s, $\mathrm{H}_{3}-13$ and $\left.\mathrm{H}_{3}-14\right) ;{ }^{1} \mathrm{H}$ NMR of the neutral form $\left(\mathrm{CD}_{3} \mathrm{OD}, 400 \mathrm{MHz}\right) \delta_{\mathrm{H}} 5.85\left(2 \mathrm{H}\right.$, br s, H-2 and $\left.\mathrm{H}-2^{\prime \prime}\right), 5.15$ (1H, m, H-6), $5.12(1 \mathrm{H}, \mathrm{m}, \mathrm{H}-10), 2.23\left(4 \mathrm{H}, \mathrm{m}, \mathrm{H}_{2}-4\right.$ and $\left.\mathrm{H}_{2}-5\right), 2.21$ ( $6 \mathrm{H}, \mathrm{br} \mathrm{s}, \mathrm{H}_{3}-15$ and $\left.\mathrm{H}_{3}-5^{\prime \prime}\right), 2.10\left(2 \mathrm{H}, \mathrm{m}, \mathrm{H}_{2}-9\right), 2.01\left(2 \mathrm{H}, \mathrm{m}, \mathrm{H}_{2}-8\right)$, $1.94\left(3 \mathrm{H}, \mathrm{s}, \mathrm{H}_{3}-4^{\prime \prime}\right), 1.69\left(3 \mathrm{H}, \mathrm{s}, \mathrm{H}_{3}-12\right), 1.65\left(3 \mathrm{H}, \mathrm{s}, \mathrm{H}_{3}-14\right), 1.62$ $\left(3 \mathrm{H}, \mathrm{s}, \mathrm{H}_{3}-13\right) ;{ }^{1} \mathrm{H}$ NMR of the protonated form $\left(\mathrm{CDCl}_{3}, 400 \mathrm{MHz}\right)$ $\delta_{\mathrm{H}} 5.85\left(1 \mathrm{H}, \mathrm{s}, \mathrm{H}-2^{\prime \prime}\right), 5.81(1 \mathrm{H}, \mathrm{s}, \mathrm{H}-2), 5.08(2 \mathrm{H}, \mathrm{m}, \mathrm{H}-6$ and $\mathrm{H}-10)$, $2.22\left(6 \mathrm{H}, \mathrm{br} s, \mathrm{H}_{3}-15\right.$ and $\left.\mathrm{H}_{3}-5^{\prime \prime}\right), 2.20\left(2 \mathrm{H}, \mathrm{m}, \mathrm{H}_{2}-4\right), 2.19(2 \mathrm{H}, \mathrm{m}$, $\left.\mathrm{H}_{2}-5\right), 2.03\left(2 \mathrm{H}, \mathrm{m}, \mathrm{H}_{2}-9\right), 1.98\left(2 \mathrm{H}, \mathrm{m}, \mathrm{H}_{2}-8\right), 1.95\left(3 \mathrm{H}, \mathrm{s}, \mathrm{H}_{3}-4^{\prime \prime}\right)$, $1.67\left(3 \mathrm{H}, \mathrm{s}, \mathrm{H}_{3}-12\right), 1.60\left(6 \mathrm{H}\right.$, br s, $\mathrm{H}_{3}-13$ and $\left.\mathrm{H}_{3}-14\right) ;{ }^{13} \mathrm{C}$ NMR of the neutral form $\left(\mathrm{CDCl}_{3}, 400 \mathrm{MHz}\right) \delta_{\mathrm{C}} 172.7\left(\mathrm{C}, \mathrm{C}-1\right.$ and $\left.\mathrm{C}-1^{\prime \prime}\right)$, 160.7 (C, C-3), 157.5 (C, C-3" and C-1'), 136.5 (C, C-7), 131.4 (C, C$11), 124.2(\mathrm{CH}, \mathrm{C}-6$ or $\mathrm{C}-10), 122.5(\mathrm{CH}, \mathrm{C}-10$ or $\mathrm{C}-6), 118.9(\mathrm{CH}$, C-2"), $118.4(\mathrm{CH}, \mathrm{C}-2), 41.5\left(\mathrm{CH}_{2}, \mathrm{C}-4\right), 39.6\left(\mathrm{CH}_{2}, \mathrm{C}-8\right), 27.9$ $\left(\mathrm{CH}_{3}, \mathrm{C}-4^{\prime \prime}\right), 26.6\left(\mathrm{CH}_{2}, \mathrm{C}-9\right), 26.1\left(\mathrm{CH}_{2}, \mathrm{C}-5\right), 25.7\left(\mathrm{CH}_{3}, \mathrm{C}-12\right)$, $20.8\left(\mathrm{CH}_{3}, \mathrm{C}-5^{\prime \prime}\right), 19.4\left(\mathrm{CH}_{3}, \mathrm{C}-15\right), 17.7\left(\mathrm{CH}_{3}, \mathrm{C}-13\right.$ or $\left.\mathrm{C}-14\right), 16.0$ $\left(\mathrm{CH}_{3}, \mathrm{C}-14\right.$ or $\left.\mathrm{C}-13\right) ;{ }^{13} \mathrm{C}$ NMR of the neutral form $\left(\mathrm{CD}_{3} \mathrm{OD}, 400\right.$ $\mathrm{MHz}) \delta_{\mathrm{C}} 175.4$ (C, C-1 and C-1" $), 160.3$ (C, C-3), 159.2 (C, C-1') 156.6 (C, C-3"), 136.6 (C, C-7), 132.2 (C, C-11), 125.3 (CH, C-10), 124.4 (CH, C-6), $121.9\left(\mathrm{CH}, \mathrm{C}-2\right.$ or C-2"), $121.7\left(\mathrm{CH}, \mathrm{C}-2^{\prime \prime}\right.$ or $\left.\mathrm{C}-2\right)$, $42.1\left(\mathrm{CH}_{2}, \mathrm{C}-4\right), 40.8\left(\mathrm{CH}_{2}, \mathrm{C}-8\right), 27.75\left(\mathrm{CH}_{3}, \mathrm{C}-4^{\prime \prime}\right), 27.66\left(\mathrm{CH}_{2}, \mathrm{C}-\right.$ 9), $27.1\left(\mathrm{CH}_{2}, \mathrm{C}-5\right), 27.0\left(\mathrm{CH}_{3}, \mathrm{C}-12\right), 20.4\left(\mathrm{CH}_{3}, \mathrm{C}-15\right.$ or $\left.\mathrm{C}-5^{\prime \prime}\right)$, $19.1\left(\mathrm{CH}_{3}, \mathrm{C}-5^{\prime \prime}\right.$ or C-15), $17.7\left(\mathrm{CH}_{3}, \mathrm{C}-13\right), 16.1\left(\mathrm{CH}_{3}, \mathrm{C}-14\right) ;{ }^{13} \mathrm{C}$ NMR of the protonated form $\left(\mathrm{CDCl}_{3}, 400 \mathrm{MHz}\right) \delta_{\mathrm{C}} 171.1(2 \mathrm{C}, \mathrm{C}-1$ and C-1"), 164.0 (C, C-3), 160.7 (C, C-3"), 136.3 (C, C-7), 131.2 (C, $\mathrm{C}-11), 124.3(\mathrm{CH}, \mathrm{C}-6$ and $\mathrm{C}-10), 118.5\left(\mathrm{CH}, \mathrm{C}-2\right.$ and $\left.\mathrm{C}-2^{\prime \prime}\right), 41.6$ $\left(\mathrm{CH}_{2}, \mathrm{C}-4\right), 39.6\left(\mathrm{CH}_{2}, \mathrm{C}-8\right), 27.9\left(\mathrm{CH}_{3}, \mathrm{C}-4^{\prime \prime}\right), 26.0\left(\mathrm{CH}_{2}, \mathrm{C}-9\right)$, $25.7\left(\mathrm{CH}_{2}, \mathrm{C}-5\right), 25.8\left(\mathrm{CH}_{3}, \mathrm{C}-12\right), 19.3\left(\mathrm{CH}_{3}, \mathrm{C}-15\right.$ and $\left.\mathrm{C}-5^{\prime \prime}\right), 16.6$ $\left(\mathrm{CH}_{3}, \mathrm{C}-13\right.$ and $\left.\mathrm{C}-14\right)$; LRESIMS $m / z 360[\mathrm{M}+\mathrm{H}]^{+}, 382[\mathrm{M}+$ $\mathrm{Na}]^{+}$; HRESIMS $m / z 360.2645$ (calcd for $\mathrm{C}_{21} \mathrm{H}_{34} \mathrm{~N}_{3} \mathrm{O}_{2}, 360.2651$ ).

Extraction and Purification of Dotofide (10). D. pinnatifida (60 individuals) were diced and sonicated in acetone $(4 \times 10 \mathrm{~mL})$ to give an aqueous acetone extract, which was concentrated by removal of the organic solvent. The aqueous residue was then extracted with $\mathrm{Et}_{2} \mathrm{O}(3$ $\times 15 \mathrm{~mL}$ ), affording $3.5 \mathrm{mg}$ of $\mathrm{Et}_{2} \mathrm{O}$ extract. This extract was fractionated on $\mathrm{SiO}_{2}$ pipet Pasteur column eluted with a gradient of $\mathrm{MeOH}$ in $\mathrm{CHCl}_{3}(0-30 \%)$. Pure dotofide $(10,1.2 \mathrm{mg}$ ) was recovered in the fraction eluted with $0.3 \%$ of $\mathrm{MeOH}$.

Dotofide (10): $[\alpha]_{\mathrm{D}}-4.3($ c $0.12, \mathrm{MeOH})$; lit. value ${ }^{13}[\alpha]_{\mathrm{D}}-3.6(c$ $0.14, \mathrm{MeOH}) ;{ }^{1} \mathrm{H}$ and ${ }^{13} \mathrm{C}$ NMR data in agreement with the literature; ${ }^{13}$ LRESIMS $m / z 360[\mathrm{M}+\mathrm{H}]^{+}, 382[\mathrm{M}+\mathrm{Na}]^{+}$; HRESIMS $m / z 360.2598$ (calcd for $\mathrm{C}_{21} \mathrm{H}_{34} \mathrm{~N}_{3} \mathrm{O}_{2}, 360.2651$ ).

Syntheses of Monoacylguanidines 2-4. Compounds 2, 3, and 4 were obtained by reaction of guanidine with farnesoic, geranoic, and senecioic acids, respectively. (E,E)-Farnesoic and $(E, E)$-geranoic acids were prepared starting from the corresponding commercial alcohols according to the literature methods, whereas senecioic acid (3,3dimethylacrylic acid) was directly purchased from Sigma-Aldrich. The reaction was performed according to Serra et al., ${ }^{17}$ and typical reaction conditions were as follows: guanidine hydrochloride $(62 \mathrm{mg}, 0.65$ $\mathrm{mmol})$ was dissolved in dry DMF/dioxane $(1: 1,2 \mathrm{~mL})$ and treated with potassium tert-butoxide $(73 \mathrm{mg}, 0.65 \mathrm{mmol})$ under a static atmosphere of nitrogen. This mixture was stirred at $50{ }^{\circ} \mathrm{C}$ for $1 \mathrm{~h}$ and then cooled to rt. Separately, the terpenoidic acid $(0.45 \mathrm{mmol})$, dissolved in dry DMF $(1 \mathrm{~mL})$, was activated by addition of CDI (73 $\mathrm{mg}, 0.45 \mathrm{mmol}$ ) portionwise at rt. After being stirred for $1 \mathrm{~h}$, the activated acid was added dropwise to the guanidine solution and the reaction was stirred for $8 \mathrm{~h}$ at rt. The reaction was quenched by addition of cool water $\left(0^{\circ} \mathrm{C}, 4 \mathrm{~mL}\right)$ and then extracted with EtOAc (3 $\times 10 \mathrm{~mL}$ ). The organic phases were combined and dried to give, after a rapid filtration on silica gel, the corresponding crude products (2, $140 \mathrm{mg} ; 3,105 \mathrm{mg} ; 4,83 \mathrm{mg}$ ). An aliquot (15 mg) of each product was purified on preparative TLC $\left(\mathrm{SiO}_{2}\right.$, light petroleum ether $/ \mathrm{Et}_{2} \mathrm{O}$, $2: 8)$ to give the corresponding pure monoacylguanidine derivatives (2, 
$3.0 \mathrm{mg} ; 3,4.5 \mathrm{mg} ; 4,5.0 \mathrm{mg}$ ). The remaining crude product from each reaction was used as such in the next step.

Farnesoyl Guanidine (2): ${ }^{1} \mathrm{H}$ NMR $\left(\mathrm{CDCl}_{3}, 400 \mathrm{MHz}\right) \delta_{\mathrm{H}} 5.85$ $(1 \mathrm{H}, \mathrm{s}, \mathrm{H}-2), 5.10(1 \mathrm{H}, \mathrm{s}, \mathrm{H}-6), 5.09(1 \mathrm{H}, \mathrm{s}, \mathrm{H}-10), 2.18\left(3 \mathrm{H}, \mathrm{s}, \mathrm{H}_{3}\right.$ 15), 2.17 (2H, m, $\left.\mathrm{H}_{2}-9\right), 2.15\left(2 \mathrm{H}, \mathrm{m}, \mathrm{H}_{2}-4\right), 2.03\left(2 \mathrm{H}, \mathrm{m}, \mathrm{H}_{2}-5\right), 1.98$ $\left(2 \mathrm{H}, \mathrm{m}, \mathrm{H}_{2}-8\right), 1.67\left(3 \mathrm{H}, \mathrm{m}, \mathrm{H}_{3}-12\right), 1.61\left(3 \mathrm{H}, \mathrm{m}, \mathrm{H}_{3}-14\right), 1.60(3 \mathrm{H}$, $\left.\mathrm{m}, \mathrm{H}_{3}-13\right) ;{ }^{13} \mathrm{C} \mathrm{NMR}\left(\mathrm{CDCl}_{3}, 400 \mathrm{MHz}\right.$, indirect detection from $2 \mathrm{D}$ heteronuclear experiments) $\delta_{\mathrm{C}} 175.4(\mathrm{C}, \mathrm{C}-1), 159.0(\mathrm{C}, \mathrm{C}-3), 136.3$ (C, C-7), 131.4 (C, C-11), 124.0 (CH, C-10), $123.2(\mathrm{CH}, \mathrm{C}-6), 121.5$ (CH, C-2), $41.0\left(\mathrm{CH}_{2}, \mathrm{C}-4\right), 40.0\left(\mathrm{CH}_{2}, \mathrm{C}-8\right), 26.3\left(\mathrm{CH}_{2}, \mathrm{C}-6\right.$ and $\mathrm{C}-$ 9), $25.8\left(\mathrm{CH}_{3}, \mathrm{C}-12\right), 19.0\left(\mathrm{CH}_{3}, \mathrm{C}-15\right), 18.1\left(\mathrm{CH}_{3}, \mathrm{C}-13\right.$ or $\left.\mathrm{C}-14\right)$, $16.6\left(\mathrm{CH}_{3}, \mathrm{C}-14\right.$ or C-13); LRESIMS $m / z 278[\mathrm{M}+\mathrm{H}]^{+}, 300[\mathrm{M}+$ $\mathrm{Na}]^{+}$; HRESIMS $m / z 278.2224$ (calcd for $\mathrm{C}_{16} \mathrm{H}_{28} \mathrm{~N}_{3} \mathrm{O}, 278.2227$ ).

Geranoyl Guanidine (3): ${ }^{1} \mathrm{H}$ NMR $\left(\mathrm{CDCl}_{3}, 400 \mathrm{MHz}\right) \delta_{\mathrm{H}} 5.78$ $(1 \mathrm{H}, \mathrm{s}, \mathrm{H}-2), 5.06(1 \mathrm{H}, \mathrm{s}, \mathrm{H}-6), 2.24-2.18$ (overlapped signals, $\mathrm{m}, 7 \mathrm{H}$, $\left.\mathrm{H}_{2}-4, \mathrm{H}_{2}-5, \mathrm{H}_{3}-10\right), 1.68\left(3 \mathrm{H}, \mathrm{m}, \mathrm{H}_{3}-8\right), 1.60\left(3 \mathrm{H}, \mathrm{m}, \mathrm{H}_{3}-9\right) ;{ }^{13} \mathrm{C}$ NMR $\left(\mathrm{CDCl}_{3}, 400 \mathrm{MHz}\right.$, indirect detection from $2 \mathrm{D}$ heteronuclear experiments) $\delta_{\mathrm{C}} 174.6(\mathrm{C}, \mathrm{C}-1), 158.4(\mathrm{C}, \mathrm{C}-3), 133.6$ (C, C-7), 122.0 (CH, C-6), $115.6(\mathrm{CH}, \mathrm{C}-2), 41.6\left(\mathrm{CH}_{2}, \mathrm{C}-4\right), 26.2\left(\mathrm{CH}_{2}, \mathrm{C}-5\right), 25.4$ $\left(\mathrm{CH}_{3}, \mathrm{C}-8\right), 19.6\left(\mathrm{CH}_{3}, \mathrm{C}-10\right), 17.5\left(\mathrm{CH}_{3}, \mathrm{C}-9\right)$; LRESIMS $\mathrm{m} / z 210$ $[\mathrm{M}+\mathrm{H}]^{+}, 232[\mathrm{M}+\mathrm{Na}]^{+}$; HRESIMS $\mathrm{m} / z 210.1600$ (calcd for $\mathrm{C}_{11} \mathrm{H}_{20} \mathrm{~N}_{3} \mathrm{O}, 210.1601$ ).

Senecioyl Guanidine (4): ${ }^{1} \mathrm{H}$ NMR $\left(\mathrm{CDCl}_{3}, 400 \mathrm{MHz}\right) \delta_{\mathrm{H}} 5.69$ $(1 \mathrm{H}, \mathrm{s}, \mathrm{H}-2), 2.14\left(3 \mathrm{H}, \mathrm{s}, \mathrm{H}_{3}-4\right), 1.89\left(3 \mathrm{H}, \mathrm{s}, \mathrm{H}_{3}-5\right) ;{ }^{13} \mathrm{C}$ NMR $\left(\mathrm{CDCl}_{3}, 400 \mathrm{MHz}\right.$, indirect detection from $2 \mathrm{D}$ heteronuclear experiments) $\delta_{\mathrm{C}} 170.9(\mathrm{C}, \mathrm{C}-1), 156.9(\mathrm{C}, \mathrm{C}-3), 116.1(\mathrm{CH}, \mathrm{C}-2)$, $27.2\left(\mathrm{CH}_{3}, \mathrm{C}-4\right), 20.3\left(\mathrm{CH}_{3}, \mathrm{C}-5\right)$; LRESIMS $\mathrm{m} / z 142[\mathrm{M}+\mathrm{H}]^{+}, 164$ $[\mathrm{M}+\mathrm{Na}]^{+}$; HRESIMS $\mathrm{m} / z 142.0977$ (calcd for $\mathrm{C}_{6} \mathrm{H}_{12} \mathrm{~N}_{3} \mathrm{O}$, 142.0975).

Syntheses of Diacylguanidines 1 and 5-9. Actinofide (1) and diacylguanidine analogues (compounds 5-9) were prepared following the synthetic scheme described in ref 17 by combining monoacylguanidines 2-4 with either farnesoic or geranoic or senecioic acid. According to Serra et al. ${ }^{17}$ the general procedure was as follows: 2chloro-1-methylpyridinium iodide $(64.0 \mathrm{mg}, 0.25 \mathrm{mmol})$ was added to a stirred solution of the terpenoic acid $(0.20 \mathrm{mmol})$ in $\mathrm{N}$ methylpyrrolidone $(1.5 \mathrm{~mL})$. The solution was stirred for $30 \mathrm{~min}$ at $\mathrm{rt}$ and then for $1 \mathrm{~h}$ at $50{ }^{\circ} \mathrm{C}$. After the reaction was cooled to rt, the monoacylguanidine derivative $(0.20 \mathrm{mmol})$ dissolved in $\mathrm{N}$-methylpyrrolidone $(0.5 \mathrm{~mL})$ and DIEA $(0.5 \mathrm{~mL})$ was added in one portion to the solution. The obtained mixture was stirred for $12 \mathrm{~h}$. The reaction was quenched by addition of $\mathrm{H}_{2} \mathrm{O}(4 \mathrm{~mL})$ and extracted with EtOAc $(3 \times 6 \mathrm{~mL})$. The organic phases were combined and concentrated under reduced pressure to give crude diacyl derivatives (1, $50 \mathrm{mg}$; 5 , $70 \mathrm{mg}$; 6, $50 \mathrm{mg}$;, $13 \mathrm{mg} ; 8,40 \mathrm{mg}$;, $60 \mathrm{mg})$. An aliquot (10-15 $\mathrm{mg}$ ) of the crude diacylguanidine obtained from each reaction was filtered on $\mathrm{SiO}_{2}$ and purified on reversed-phase HPLC [Supelco Discovery C18 $(25 \mathrm{~cm} \times 10 \mathrm{~mm}, 5 \mu \mathrm{m})$ column, $35 \mathrm{~min}$ gradient from 50 to $100 \% \mathrm{MeOH}$ in $\mathrm{H}_{2} \mathrm{O}$ with $0.1 \%$ of TFA, flow $2 \mathrm{~mL} / \mathrm{min}$, UV detector at $\lambda=210$ and $254 \mathrm{~nm}$ ] to give the corresponding pure diacylguanidine derivatives (1,3.1 mg; 5, $2.5 \mathrm{mg} ; 6,2.0 \mathrm{mg} ; 7,1.8 \mathrm{mg}$; $8,3.5 \mathrm{mg} ; 9,1.5 \mathrm{mg}$ ), as TFA salts.

Actinofide (1): ${ }^{1} \mathrm{H}$ and ${ }^{13} \mathrm{C}$ NMR data of synthetic 1 were identical to those of the natural compound; LRESIMS $\mathrm{m} / z 360[\mathrm{M}+\mathrm{H}]^{+}, 382$ $[\mathrm{M}+\mathrm{Na}]^{+}$; HRESIMS $\mathrm{m} / \mathrm{z} 360.2643$ (calcd for $\mathrm{C}_{21} \mathrm{H}_{34} \mathrm{~N}_{3} \mathrm{O}_{2}$, 360.2651).

$N, N^{\prime}$-Difarnesoyl Guanidine (5): ${ }^{1} \mathrm{H}$ NMR $\left(\mathrm{CDCl}_{3}, 400 \mathrm{MHz}\right) \delta_{\mathrm{H}}$ $5.85\left(2 \mathrm{H}, \mathrm{s}, \mathrm{H}-2\right.$ and $\left.\mathrm{H}-2^{\prime \prime}\right), 5.09\left(4 \mathrm{H}, \mathrm{m}, \mathrm{H}-6, \mathrm{H}-10, \mathrm{H}-6^{\prime \prime}\right.$, and $\mathrm{H}-$ $\left.10^{\prime \prime}\right), 2.20\left(6 \mathrm{H}, \mathrm{s}, \mathrm{H}_{3}-15\right.$ and $\left.\mathrm{H}_{3}-15^{\prime \prime}\right), 2.18\left(8 \mathrm{H}, \mathrm{m}, \mathrm{H}_{2}-4, \mathrm{H}_{2}-5, \mathrm{H}_{2}-4^{\prime \prime}\right.$, and $\left.\mathrm{H}_{2}-5^{\prime \prime}\right), 2.06\left(4 \mathrm{H}, \mathrm{m}, \mathrm{H}_{2}-9\right.$ and $\left.\mathrm{H}_{2}-9^{\prime \prime}\right), 1.99\left(4 \mathrm{H}, \mathrm{m}, \mathrm{H}_{2}-8\right.$ and $\mathrm{H}_{2}-$ $\left.8^{\prime \prime}\right), 1.68\left(6 \mathrm{H}, \mathrm{m}, \mathrm{H}_{3}-12\right.$ and $\left.\mathrm{H}_{3}-12^{\prime \prime}\right), 1.605\left(6 \mathrm{H}, \mathrm{m}, \mathrm{H}_{3}-14\right.$ and $\mathrm{H}_{3}-$ $\left.14^{\prime \prime}\right), 1.599\left(6 \mathrm{H}, \mathrm{m}, \mathrm{H}_{3}-13\right.$ and $\left.\mathrm{H}_{3}-13^{\prime \prime}\right) ;{ }^{13} \mathrm{C} \mathrm{NMR}\left(\mathrm{CDCl}_{3}, 400 \mathrm{MHz}\right.$, indirect detection from $2 \mathrm{D}$ heteronuclear experiments) $\delta_{\mathrm{C}} 174.4(\mathrm{C}$, C-1), 159.8 (C, C-3 and C-3"), 135.7 (C, C-7 and C-7"), 131.1 (C, C11 and $\left.\mathrm{C}-11^{\prime \prime}\right), 123.6\left(\mathrm{CH}, \mathrm{C}-6, \mathrm{C}-10, \mathrm{C}-6^{\prime \prime}\right.$, and C-10"), $120.5(\mathrm{CH}$, $\mathrm{C}-2$ and $\left.\mathrm{C}-2^{\prime \prime}\right), 41.7\left(\mathrm{CH}_{2}, \mathrm{C}-4\right.$ and C-4" $), 39.5\left(\mathrm{CH}_{2}, \mathrm{C}-8\right.$ and C-8" $)$, $26.7\left(\mathrm{CH}_{2}, \mathrm{C}-9\right.$ and $\left.\mathrm{C}-9^{\prime \prime}\right), 25.9\left(\mathrm{CH}_{2}, \mathrm{C}-5\right.$ and $\left.\mathrm{C}-5^{\prime \prime}\right), 25.3\left(\mathrm{CH}_{3}, \mathrm{C}-\right.$ 12 and $\left.\mathrm{C}-12^{\prime \prime}\right), 19.0\left(\mathrm{CH}_{3}, \mathrm{C}-15\right.$ and $\left.\mathrm{C}-15^{\prime \prime}\right), 17.4\left(\mathrm{CH}_{3}, \mathrm{C}-13\right.$ and $\mathrm{C}-$ $\left.13^{\prime \prime}\right), 16.3\left(\mathrm{CH}_{3}, \mathrm{C}-14\right.$ and C-14"); LRESIMS $m / z 496[\mathrm{M}+\mathrm{H}]^{+}, 518$
$[\mathrm{M}+\mathrm{Na}]^{+}$; HRESIMS $m / z 496.3901$ (calcd for $\mathrm{C}_{31} \mathrm{H}_{50} \mathrm{~N}_{3} \mathrm{O}_{2}$, 496.3902).

$N, N^{\prime}$-Digeranoyl Guanidine (6): ${ }^{1} \mathrm{H}$ NMR $\left(\mathrm{CDCl}_{3}, 400 \mathrm{MHz}\right) \delta_{\mathrm{H}}$ $5.78\left(2 \mathrm{H}, \mathrm{s}, \mathrm{H}-2\right.$ and $\left.\mathrm{H}-2^{\prime \prime}\right), 5.08\left(2 \mathrm{H}, \mathrm{m}, \mathrm{H}-6\right.$ and $\left.\mathrm{H}-6^{\prime \prime}\right), 2.19(6 \mathrm{H}, \mathrm{s}$, $\mathrm{H}_{3}-10$ and $\left.\mathrm{H}_{3}-10^{\prime \prime}\right), 2.17\left(8 \mathrm{H}, \mathrm{m}, \mathrm{H}_{2}-4, \mathrm{H}_{2}-5, \mathrm{H}_{2}-4^{\prime \prime}\right.$, and $\left.\mathrm{H}_{2}-5^{\prime \prime}\right), 1.69$ $\left(6 \mathrm{H}, \mathrm{m}, \mathrm{H}_{3}-8\right.$ and $\left.\mathrm{H}_{3}-8^{\prime \prime}\right), 1.61\left(6 \mathrm{H}, \mathrm{m}, \mathrm{H}_{3}-9\right.$ and $\left.\mathrm{H}_{3}-9^{\prime \prime}\right) ;{ }^{13} \mathrm{C}$ NMR $\left(\mathrm{CDCl}_{3}, 400 \mathrm{MHz}\right.$, indirect detection from $2 \mathrm{D}$ heteronuclear experiments) $\delta_{\mathrm{C}} 175.4(\mathrm{C}, \mathrm{C}-1), 160.0$ (C, C-3 and C-3"), 133.0 (C, C-7 and C-7"), $123.0(\mathrm{CH}, \mathrm{C}-6$ and C-6" $), 119.8(\mathrm{CH}, \mathrm{C}-2$ and $\mathrm{C}-$ $\left.2^{\prime \prime}\right), 41.4\left(\mathrm{CH}_{2}, \mathrm{C}-4\right.$ and $\left.\mathrm{C}-4^{\prime \prime}\right), 26.3\left(\mathrm{CH}_{2}, \mathrm{C}-5\right.$ and $\left.\mathrm{C}-5{ }^{\prime \prime}\right), 25.3\left(\mathrm{CH}_{3}\right.$, C-8 and C-8" $), 18.8\left(\mathrm{CH}_{3}, \mathrm{C}-10\right.$ and C-10"), $17.8\left(\mathrm{CH}_{3}, \mathrm{C}-9\right.$ and C$\left.9^{\prime \prime}\right)$; LRESIMS $m / z 360[\mathrm{M}+\mathrm{H}]^{+}, 382[\mathrm{M}+\mathrm{Na}]^{+}$; HRESIMS $m / z$ 360.2647 (calcd for $\mathrm{C}_{21} \mathrm{H}_{34} \mathrm{~N}_{3} \mathrm{O}_{2}, 360.2651$ ).

$\mathrm{N}, \mathrm{N}^{\prime}$-Disenecioyl Guanidine (7): ${ }^{1} \mathrm{H}$ NMR $\left(\mathrm{CDCl}_{3}, 400 \mathrm{MHz}\right) \delta_{\mathrm{H}}$ $5.77\left(2 \mathrm{H}, \mathrm{s}, \mathrm{H}-2\right.$ and $\left.\mathrm{H}-2^{\prime \prime}\right), 2.22\left(6 \mathrm{H}, \mathrm{s}, \mathrm{H}_{3}-4\right.$ and $\left.\mathrm{H}_{3}-4^{\prime \prime}\right), 1.96(6 \mathrm{H}, \mathrm{s}$, $\mathrm{H}_{3}-5$ and $\left.\mathrm{H}_{3}-5^{\prime \prime}\right) ;{ }^{13} \mathrm{C} \mathrm{NMR}\left(\mathrm{CDCl}_{3}, 400 \mathrm{MHz}\right.$, indirect detection from $2 \mathrm{D}$ heteronuclear experiments) $\delta_{\mathrm{C}} 166.9\left(\mathrm{C}, \mathrm{C}-1\right.$ and $\left.\mathrm{C}-1^{\prime \prime}\right)$, 158.8 (C, C-3 and C-3"), $117.2\left(\mathrm{CH}, \mathrm{C}-2\right.$ and C-2"), $27.9\left(\mathrm{CH}_{3}, \mathrm{C}-4\right.$ and $\left.\mathrm{C}-4^{\prime \prime}\right), 20.9\left(\mathrm{CH}_{3}, \mathrm{C}-5\right.$ and C-5"); LRESIMS $m / z 224[\mathrm{M}+\mathrm{H}]^{+}$, $246[\mathrm{M}+\mathrm{Na}]^{+}$; HRESIMS $m / z 224.1394$ (calcd for $\mathrm{C}_{11} \mathrm{H}_{18} \mathrm{~N}_{3} \mathrm{O}_{2}$, 224.1399).

N-Geranoyl-N'-senecioyl Guanidine (8): ${ }^{1} \mathrm{H}$ NMR $\left(\mathrm{CDCl}_{3}, 400\right.$ $\mathrm{MHz}) \delta_{\mathrm{H}} 5.78\left(1 \mathrm{H}, \mathrm{s}, \mathrm{H}-2^{\prime \prime}\right), 5.75(1 \mathrm{H}, \mathrm{s}, \mathrm{H}-2), 5.07(1 \mathrm{H}, \mathrm{m}, \mathrm{H}-6)$, $2.20\left(6 \mathrm{H}, \mathrm{s}, \mathrm{H}_{3}-10\right.$ and $\left.\mathrm{H}_{3}-5^{\prime \prime}\right), 2.17\left(4 \mathrm{H}, \mathrm{m}, \mathrm{H}_{2}-4, \mathrm{H}_{2}-5\right), 1.92(3 \mathrm{H}, \mathrm{m}$, $\left.\mathrm{H}_{3}-4^{\prime \prime}\right), 1.69\left(3 \mathrm{H}, \mathrm{m}, \mathrm{H}_{3}-8\right), 1.61\left(3 \mathrm{H}, \mathrm{m}, \mathrm{H}_{3}-9\right) ;{ }^{13} \mathrm{C} \mathrm{NMR}\left(\mathrm{CDCl}_{3}\right.$, $400 \mathrm{MHz}$, indirect detection from $2 \mathrm{D}$ heteronuclear experiments) $\delta_{\mathrm{C}}$ 172.4 (C, C-1 and C-1"), 161.3 (C, C-3), 157.1(C, C-3"), 132.6 (C, C-7), $122.4(\mathrm{CH}, \mathrm{C}-6), 120.0\left(\mathrm{CH}, \mathrm{C}-2^{\prime \prime}\right), 119.4(\mathrm{CH}, \mathrm{C}-2), 41.3$ $\left(\mathrm{CH}_{2}, \mathrm{C}-4\right), 27.8\left(\mathrm{CH}_{3}, \mathrm{C}-4^{\prime \prime}\right), 26.0\left(\mathrm{CH}_{2}, \mathrm{C}-5\right), 25.9\left(\mathrm{CH}_{3}, \mathrm{C}-8\right)$, $20.3\left(\mathrm{CH}_{3}, \mathrm{C}-5^{\prime \prime}\right), 18.6\left(\mathrm{CH}_{3}, \mathrm{C}-10\right), 17.6\left(\mathrm{CH}_{3}, \mathrm{C}-9\right)$; LRESIMS $\mathrm{m} / z$ $292[\mathrm{M}+\mathrm{H}]^{+}, 314[\mathrm{M}+\mathrm{Na}]^{+}$; HRESIMS $m / z 292.2019$ (calcd for $\left.\mathrm{C}_{16} \mathrm{H}_{26} \mathrm{~N}_{3} \mathrm{O}_{2}, 292.2025\right)$.

N-Farnesoyl-N'-geranoyl Guanidine (9): ${ }^{1} \mathrm{H}$ NMR $\left(\mathrm{CDCl}_{3}, 400\right.$ $\mathrm{MHz}) \delta_{\mathrm{H}} 5.71\left(2 \mathrm{H}, \mathrm{s}, \mathrm{H}-2\right.$ and $\left.\mathrm{H}-2^{\prime \prime}\right), 5.09$ (4H, m, H-6, H-10, H-6", and $\mathrm{H}-10^{\prime \prime}$ ), $2.21-2.17$ (overlapped signals, $14 \mathrm{H}, \mathrm{H}_{2}-4, \mathrm{H}_{2}-5, \mathrm{H}_{3}-15$, $\mathrm{H}_{2}-4^{\prime \prime}, \mathrm{H}_{2}-5^{\prime \prime}$, and $\left.\mathrm{H}_{3}-10^{\prime \prime}\right), 2.06\left(2 \mathrm{H}, \mathrm{m}, \mathrm{H}_{2}-9\right), 1.99\left(2 \mathrm{H}, \mathrm{m}, \mathrm{H}_{2}-8\right)$, $1.68\left(6 \mathrm{H}, \mathrm{m}, \mathrm{H}_{3}-12\right.$ and $\left.\mathrm{H}_{3}-8^{\prime \prime}\right), 1.605\left(3 \mathrm{H}, \mathrm{m}, \mathrm{H}_{3}-14\right), 1.602(6 \mathrm{H}, \mathrm{m}$, $\mathrm{H}_{3}-13$ and $\left.\mathrm{H}_{3}-9^{\prime \prime}\right) ;{ }^{13} \mathrm{C}$ NMR $\left(\mathrm{CDCl}_{3}, 400 \mathrm{MHz}\right.$, indirect detection from $2 \mathrm{D}$ heteronuclear experiments) $\delta_{\mathrm{C}} 170.9(\mathrm{C}, \mathrm{C}-1), 162.2(\mathrm{C}, \mathrm{C}-3$ and C-3"), $136.3(\mathrm{C}, \mathrm{C}-7), 131.2\left(\mathrm{C}, \mathrm{C}-11\right.$ and $\left.\mathrm{C}-7^{\prime \prime}\right), 123.6(\mathrm{CH}, \mathrm{C}-$ 6, C-10, C-6"), $114.7(\mathrm{CH}, \mathrm{C}-2$ and C-2" $), 41.1\left(\mathrm{CH}_{2}, \mathrm{C}-4\right.$ and $\left.\mathrm{C}-4^{\prime \prime}\right)$, $39.2\left(\mathrm{CH}_{2}, \mathrm{C}-8\right), 26.4\left(\mathrm{CH}_{2}, \mathrm{C}-9\right), 25.9\left(\mathrm{CH}_{2}, \mathrm{C}-5\right.$ and $\left.\mathrm{C}-5^{\prime \prime}\right), 25.5$ $\left(\mathrm{CH}_{3}, \mathrm{C}-12\right.$ and $\left.\mathrm{C}-8^{\prime \prime}\right), 19.0\left(\mathrm{CH}_{3}, \mathrm{C}-15\right.$ and $\left.\mathrm{C}-10^{\prime \prime}\right), 17.5\left(\mathrm{CH}_{3}, \mathrm{C}-13\right.$ and C-9"), $16.4\left(\mathrm{CH}_{3}, \mathrm{C}-14\right)$; LRESIMS $m / z 428[\mathrm{M}+\mathrm{H}]^{+}, 450[\mathrm{M}$ $+\mathrm{Na}]^{+}$; HRESIMS $m / z 428.3272$ (calcd for $\mathrm{C}_{26} \mathrm{H}_{42} \mathrm{~N}_{3} \mathrm{O}_{2}, 428.3277$ ).

In Vitro Growth Inhibitory Measurements. The six cancer cell lines studied were obtained either from the American Type Culture Collection (ATCC), the European Collection of Cell Culture (ECACC), or the Deutsche Sammlung von Mikroorganismen and Zellkulturen (DSMZ). The origin and histological type of each cell line analyzed are detailed in the legend to Table 1 .

The various cancer cell lines were cultured in RPMI culture medium (Lonza code BE12-115F) supplemented with $10 \%$ heat-inactivated fetal bovine serum (Life Technologies code 10270106), $4 \mathrm{mM}$ glutamine (Lonza code BE17-605E), $100 \mu \mathrm{g} / \mathrm{mL}$ gentamicin (Lonza code BE17-518Z), and penicillin-streptomycin (200 units $/ \mathrm{mL}$ and $200 \mathrm{mg} / \mathrm{mL}$ ) (Lonza code BE17-602E). The in vitro growth inhibitory activity of the various compounds was determined by means of the MTT colorimetric assay as detailed previously. ${ }^{18-20}$

\section{ASSOCIATED CONTENT}

\section{Supporting Information}

The Supporting Information is available free of charge on the ACS Publications website at DOI: 10.1021/acs.jnatprod.6b00941.

${ }^{1} \mathrm{H},{ }^{13} \mathrm{C}, 2 \mathrm{D} \mathrm{NMR}$, and MS spectra of compounds 1-10 (PDF) 


\section{AUTHOR INFORMATION}

\section{Corresponding Authors}

*Phone/fax (Y.-W. Guo): +86 21 50805813. E-mail: ywguo@ simm.ac.cn.

*Fax (M. Gavagnin): +39 0818041770 . E-mail: mgavagnin@ icb.cnr.it.

ORCID $\odot$

Margherita Gavagnin: 0000-0002-9532-4555

\section{Notes}

The authors declare no competing financial interest.

\section{ACKNOWLEDGMENTS}

This research work was financially supported by a grant from MIUR-ITALY PRIN2015 “Top-down and bottom-up approach in the development of new bioactive chemical entities inspired on natural products scaffolds" (Project No. 2015MSCKCE_003), CNR (Italy)/ASM (Moldova) Joint Bilateral Project 2015/2017, and NSFC key international collaboration Project No. 81520108028. The authors thank Mrs. D. Melck and Mr. E. Mirra of ICB-NMR service for technical assistance, Dr. G. Villani for collection and identification of $D$. pinnatifida, and Mrs. D. Ricciardi for laboratory support. ICB/mass spectrometry service provided by Dr. A. Cutignano, Dr. F. Piscitelli, and Mr. M. Zampa is gratefully acknowledged. R.K. is a director of research with the Fonds National de la Recherche Scientifique (FRS-FNRS, Belgium). Part of the current study was granted by the Belgian Brain Tumor Group (BBTS, Belgium).

\section{REFERENCES}

(1) Berlinck, R. G. S.; Romminger, S. Nat. Prod. Rep. 2016, 33, 456490 and previous reports in this series.

(2) Berlinck, R. G. S.; Kossuga, M. H. In Modern Alkaloids: Structure, Isolation, Synthesis and Biology; Fattorusso, E., Taglialatela-Scafati, O., Eds.; Wiley-VCH Verlag GmbH \& Co. KGaA: Weinheim, Germany, 2008.

(3) Ebada, S. S.; Proksch, P. Mini-Rev. Med. Chem. 2011, 11, 225246.

(4) (a) Berlinck, R. G. S. In Progress in the Chemistry of Organic Natural Products; Herz, W., Kirby, G. W., Moore, R. E., Steglich, W., Tamm, Ch., Eds.; Springer-Verlag: Vienna, Austria, 1995; Vol. 66, pp 119-295. (b) Saczewski, F.; Balewski, I. Expert Opin. Ther. Pat. 2013, 23, 965-995. and previous reports in this series (c) Mori, A.; Cohen, B. D.; Koide, H. Guanidines 2. Further Explorations of Biological and Clinical Significance of Guanidino Compounds; Plenum Press: New York, 1989.

(5) Rauf, M. K.; Imtiaz-ud-Din; Badshah, A. Expert Opin. Drug Discovery 2014, 9, 39-53.

(6) Saczewski, F.; Balewski, L. Expert Opin. Ther. Pat. 2013, 23, 965995.

(7) Ghorai, P.; Kraus, A.; Keller, M.; Götte, C.; Igel, P.; Schneider, E.; Schnell, D.; Bernhardt, G.; Dove, S.; Zabel, M.; Elz, S.; Seifert, R.; Buschauer, A. J. Med. Chem. 2008, 51, 7193-7204.

(8) Keller, M.; Pop, N.; Hutzler, C.; Beck-Sickinger, A. G.; Bernhardt, G.; Buschauer, A. J. Med. Chem. 2008, 51, 8168-8172.

(9) Kleinmaier, R.; Keller, M.; Igel, P.; Buschauer, A.; Gschwind, R. M. J. Am. Chem. Soc. 2010, 132, 11223-11233.

(10) Ciavatta, M. L.; Lefranc, F.; Carbone, M.; Mollo, E.; Gavagnin, M.; Betancourt, T.; Dasari, R.; Kornienko, A.; Kiss, R. Med. Res. Rev. 2016, DOI: $10.1002 /$ med.21423.

(11) (a) Carbone, M.; Irace, C.; Li, Y.; Mollo, E.; Castelluccio, F.; Di Pascale, A.; Cimino, G.; Santamaria, R.; Guo, Y.-W.; Gavagnin, M. Org. Lett. 2011, 13, 2516-2519. (b) Manzo, E.; Pagano, D.; Ciavatta, M. L.; Carbone, M.; Gavagnin, M. U.S. Patent 9.085.569, 2015. (c) Vitale, R.
M.; Gatti, M.; Carbone, M.; Barbieri, F.; Felicità, V.; Gavagnin, M.; Florio, T.; Amodeo, P. ACS Chem. Biol. 2013, 8, 2762-2770.

(12) Manzo, E.; Carbone, M.; Mollo, E.; Irace, C.; Di Pascale, A.; Li, Y.; Ciavatta, M. L.; Cimino, G.; Guo, Y.-W.; Gavagnin, M. Org. Lett. 2011, 13, 1897-1899.

(13) Putz, A.; Kehraus, S.; Díaz-Agras, G.; Wägele, H.; König, G. M. Eur. J. Org. Chem. 2011, 2011, 3733-3737.

(14) (a) Hart, N. K.; Johns, S. R.; Lamberton, J. A. J. Chem. Soc. D 1969, 1484-1485. (b) Ngamga, D.; Free, S. N. Y. F.; Fomum, Z. T.; Chiaroni, A.; Riche, C.; Martin, M. T.; Bodo, B. J. Nat. Prod. 1993, 56, 2126-2132. (c) Kamnaing, P.; Yurika Fanso Free, S. N.; Fomum, Z. T.; Martin, M. T.; Bodo, B. Phytochemistry 1994, 36, 1561-1562. (d) Bolzani, V. S.; Gunatilaka, A. A.; Kingston, D. G. J. Nat. Prod. 1995, 58, 1683-1688. (e) Regasini, L. O.; Castro-Gamboa, I.; Silva, D. H.; Furlan, M.; Barreiro, E. J.; Ferreira, P. M.; Pessoa, C.; Lotufo, L. V.; de Moraes, M. O.; Young, M. C.; Bolzani, V. S. J. Nat. Prod. 2009, 72, 473-476.

(15) (a) Mooney, M. H.; Fogarty, S.; Stevenson, C.; Gallagher, A. M.; Palit, P.; Hawley, S. A.; Hardie, D. G.; Coxon, G. D.; Waigh, R. D.; Tate, R. J.; Harvey, A. L.; Furman, B. L. Br. J. Pharmacol. 2008, 153, 1669-1677. (b) Tajima, Y.; Murase, H.; Satake, K.; Mitani, Y.; Regasini, L. O.; da Silva Bolzani, V.; Efferth, T.; Nakagawa, H. Cytotechnology 2015, 67, 585-592. (c) Siqueira, M. C.; Silva, M. T. A.; Regasini, L. O.; Silva, D. H. S.; Cicarelli, R. M. B. Planta Med. 2009, 75, 945. (d) Carmignani, M.; Volpe, A. R.; Delle Monache, F.; Botta, B.; Espinal, R.; De Bonnevaux, S. C.; De Luca, C.; Botta, M.; Corelli, F.; Tafi, A.; Ripanti, G.; Delle Monache, G. J. Med. Chem. 1999, 42, $3116-3125$

(16) Tajima, Y.; Nakagawa, H.; Tamura, A.; Kadioglu, O.; Satake, K.; Mitani, Y.; Murase, H.; Regasini, L. O.; da Silva Bolzani, V.; Ishikawa, T.; Fricker, G.; Efferth, T. Phytomedicine 2014, 21, 323-332.

(17) Serra, S.; Cominetti, A. A.; Lissoni, V. Nat. Prod. Commun. 2014, 9, 329-335.

(18) Mathieu, V.; Le Mercier, M.; De Neve, N.; Sauvage, S.; Gras, T.; Roland, I.; Lefranc, F.; Kiss, R. J. Invest. Dermatol. 2007, 127, 23992410.

(19) Lefranc, F.; Nuzzo, G.; Hamdy, N. A.; Fakhr, I.; Moreno Y Banuls, L.; Van Goietsenoven, G.; Villani, G.; Mathieu, V.; van Soest, R.; Kiss, R.; Ciavatta, M. L. J. Nat. Prod. 2013, 76, 1541-1547.

(20) Cimmino, A.; Mathieu, V.; Masi, M.; Baroncelli, R.; Boari, A.; Pescitelli, G.; Ferderin, M.; Lisy, R.; Evidente, M.; Tuzi, A.; Zonno, M. C.; Kornienko, A.; Kiss, R.; Evidente, A. J. Nat. Prod. 2016, 79, 116125.

(21) Dumont, P.; Ingrassia, L.; Rouzeau, S.; Ribaucour, F.; Thomas, S.; Roland, I.; Darro, F.; Lefranc, F.; Kiss, R. Neoplasia 2007, 9, 766776.

(22) Branle, F.; Lefranc, F.; Camby, I.; Jeuken, J.; Geurts-Moespot, A.; Sprenger, S.; Sweep, F.; Kiss, R.; Salmon, I. Cancer 2002, 95, 641655.

(23) Le Mercier, M.; Fortin, S.; Mathieu, V.; Roland, I.; SpieglKreinecker, S.; Haibe-Kains, B.; Bontempi, G.; Decaestecker, C.; Berger, W.; Lefranc, F.; Kiss, R. Neoplasia 2009, 11, 485-496.

(24) Mathieu, V.; De Neve, N.; Le Mercier, M.; Dewelle, J.; Gaussin, J. F.; Dehoux, M.; Kiss, R.; Lefranc, F. Neoplasia 2008, 10, 1383-1392.

(25) Van Goietsenoven, G.; Hutton, J.; Becker, J. P.; Lallemand, B.; Robert, F.; Lefranc, F.; Pirker, C.; Vandenbussche, G.; Van Antwerpen, P.; Evidente, A.; Berger, W.; Prévost, M.; Pelletier, J.; Kiss, R.; Goss Kinzy, T.; Kornienko, A.; Mathieu, V. FASEB J. 2010, 24, 4575-4584.

(26) Kelly, G. L.; Strasser, A. Adv. Cancer Res. 2011, 111, 39-96.

(27) Mohammad, R. M.; Muqbil, I.; Lowe, L.; Yedjou, C.; Hsu, H. Y.; Lin, L. T.; Siegelin, M. D.; Fimognari, C.; Kumar, N. B.; Dou, Q. P.; Yang, H.; Samadi, A. K.; Russo, G. L.; Spagnuolo, C.; Ray, S. K.; Chakrabarti, M.; Morre, J. D.; Coley, H. M.; Honoki, K.; Fujii, H.; Georgakilas, A. G.; Amedei, A.; Niccolai, E.; Amin, A.; Ashraf, S. S.; Helferich, W. G.; Yang, X.; Boosani, C. S.; Guha, G.; Bhakta, D.; Ciriolo, M. R.; Aquilano, K.; Chen, S.; Mohammed, S. I.; Keith, W. N.; Bilsland, A.; Halicka, D.; Nowsheen, S.; Azmi, A. S. Semin. Cancer Biol. 2015, 35, S78-S103. 
(28) Liu, W.; Vivian, C. J.; Brinker, A. E.; Hampton, K. R.; Lianidou, E.; Welch, D. R. Cancer Microenviron. 2014, 7, 117-131.

(29) Simpson, C. D.; Anyiwe, K.; Schimmer, A. D. Cancer Lett. 2008, 272, 177-185.

(30) Kornienko, A.; Mathieu, V.; Rastogi, S. K.; Lefranc, F.; Kiss, R. J. Med. Chem. 2013, 56, 4823-4839.

(31) Mathieu, V.; Remmelink, M.; D’Haene, N.; Penant, S.; Gaussin, R.; Van Ginckel, J. F.; Darro, F.; Kiss, R.; Salmon, I. Cancer 2004, 101, 1908-1918.

(32) Van Goietsenoven, G.; Mathieu, V.; Andolfi, A.; Cimmino, A.; Lefranc, F.; Kiss, R.; Evidente, A. Planta Med. 2011, 77, 711-717.

(33) Lefranc, F.; Brotchi, J.; Kiss, R. J. Clin. Oncol. 2005, 23, 24112422.

(34) Soengas, M. S.; Lowe, S. W. Oncogene 2003, 22, 3138-3151. 